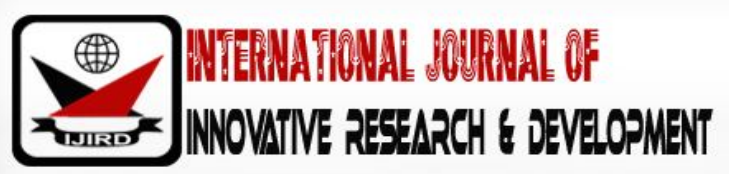

ISSN 2278 - 0211 (Online)

\section{Financial Innovations and Financial Performance of Commercial Banks}

\author{
Kurgat David Kiplangat \\ Accountant Officer, Kenyatta University, Kenya \\ Dr. Charles Tibbs
}

Lecturer- Finance, Department of Business Administration, Kenyatta University, Kenya

\begin{abstract}
:
Advances in innovation and changing financial conditions have made driving force for this change. Because of serious global rivalry, divided and requesting markets and the quickly evolving advances, developments have turned out to be a standout amongst the most important elements for business banks. The present investigation was prompted by the present difficulties in the managing an account division. With the closure of Imperial Bank and Chase bank in Kenya being put under receivership, it was clear that were not challenges in the saving money division and Central Bank of Kenya should take measures to protect customers from future misfortunes. The principle goal of this investigation was established the influence of financial innovations on the financial performance of commercial banks in Kenya. Causal research design was used to complete this investigation. The objective population for this study included 215 workers of business banks in Kenya. The sample estimate was 170 respondents that was collected using stratified random sampling. Inferential statistics was used to produce the results. The findings indicated that innovation significantly affected financial performance. The highest direct contributor come from mobile banking based on the levy and charges used and its convenience. Online banking, EFT and agency banking were not significant predictors but was indirectly like to financial growth in liquidity aspect. It provided more customer base as well as open new untouched market. The research recommended that agency and online banking should be exploited further as a potential area for more financial performance this can be done through introduction of mobile operated applications. Further research should also be done in the two areas.
\end{abstract}

Keywords: Financial innovation, financial performance, causal study, Kenya

\section{Introduction}

The Kenyan financial sector has experienced tremendous dynamism over time. A great deal of changes have been embraced in the area that have prompted expansion of money related items, exercises and hierarchical structures that have enhanced and expanded the productivity of the monetary framework. Advances in innovation and changing financial conditions have necessitated this change. Innovations involve firms developing new things or new age strategies to better play out their operations, in which case the new things could be established on the new methods. In the money related organizations industry, Innovation is viewed as the show of making and advancing new budgetary instruments, advances, foundations and markets, which urge access to information, trading and strategies for installment. Lerner (2006) advances that developments are not only basic for firms in the monetary administrations industry, yet in addition influence different organizations; for example, assisting the institution to bring capital up in greater aggregates at minimal expenses for some way or another and that improvement is a basic ponder in any portion of a cutting-edge economy. Financial innovations encompass a lot of radical changes in the financial sector which bring about positive changes in terms of the financial outcome, diversification, international structural makeover and erudition of the financial structure. All this leads to further funding of the financial system whereby financial assets to total assets ratio tends to increase. It is without regard to this background that this study seeks to provide the effects of financial innovations on the financial performance of commercial banks in Kenya with Cooperative Bank being a case in point. These financial innovations are the unforeseen change in the variety of monetary items and instruments that are empowered by surprising change in client needs and inclinations; assess strategy, innovation and administrative motivations (Bhattacharyya and Nanda, 2000).

A firm's financial performance is explained as how much money related uses or objectives are being or have been proficient. It is the way toward measuring the after effects of an association's strategies and operations in financial terms. It is utilized to quantify association's general monetary wellbeing over a given timeframe and can likewise be utilized to look at 
comparative firms over a similar industry or to think about enterprises or parts in conglomeration. Ahmad et al, (2011) contends that the benefit of commercial banks depends intensely on the net of wage creating exercises and the related exercises cost. Because of the issue of benefit and firm rivalry in the banking industry, business banks have changed their income sources behavior by progressively broadening into non-intermediation income creating exercises instead of the conventional intermediation income producing exercises (McKay and Pickens, 2010). For any financial institution to stay aggressive there is need to create and embrace new items and innovation. Such items incorporate selection of Islamic products, utilization of innovation i.e. online banking and mobile banking.

\section{Literature Review}

The review of several scholars both in theories and imperial provide a knowledge links on the financial innovation and performance in a firm.

\subsection{Theoretical Foundation}

This paper reviews looks into the various theories as regards this research and they includes; innovation diffusion theory, agency theory, technology acceptance model and transactions cost innovative theory. These theories informed the study of the source of the variables as well as the interactions between the dependent and independent variables.

\subsubsection{Innovation Diffusion Theory}

Gardachew (2010) in his study came up with the factors influencing diffusion of an innovation and they included; pros (that explained how far technology offers in improving the available tools currently), compatibility (which typically explained the consistency in regard to the social practices and norms among the stakeholders), complexity (which simply eased the use and learning), trialability (which brought about opportunities that helped in trying innovation before putting it to use), and observability (which explained how much ICT outputs and its importance is visible). The outlined factors are not all exclusive and hence cannot help in the prediction of the extent as well as the rate at which innovation diffuses.

\subsubsection{Technology Acceptance Model}

This basically entails an explanation based on the Theories and models used in research associated with acceptable new technology and innovation. Davis (1989) discusses in technological issues and contributed to TAM. TAM model seeks to link the persons' behavioral intentions when using ICT. A suggestion has been brought about and it is; a person's real reaction is determined by his behavioral intention to use and the same is affects the user's life perception toward the value of the innovation and the value of the later is resolved by straightforwardness of its utilization. The usage of TAM model works well with ease and convenience end-clients modification and integration (Pedersen, Leif, Methlie and Thorbjornsen, 2002). The importance and familiarity of this model have an effect on the user's perception in regards to any service provided (ibid.). Davis $(1989 ; 1993)$ in his study thus came up with the significance of value user necessity based on an observation that has helpfulness and how innovations are used in its place of other measures. Critiques of this model take after a choice that is slanted to the innovative where section of the innovation in reference ignores diverse factors, for example, social part of the clients yet in genuine practice, limitations which incorporates; restricted time, capacity, hierarchical or ecological cutoff points and oblivious propensities restrains the flexibility of actions.

\subsubsection{Transactions Cost Innovative Theory}

The theory was explained by guidance of transactions cost innovative theory which was introduced by Hicks \& Niehans (1983) who championed and stated that the foremost aspect of financial innovation is to be able to reduce cost of transaction which responds to the advancement in technology and which resulted in the reduction of transaction cost. The ability to lower the cost of transaction brings about innovation in financial and upgrading of financial service and the same believes that money related innovations decreases the costs involved in making transactions. The importance of Transaction costs Innovation theory in the set-up of Internet-related Information Technology (IT) considerably lessens a company's exchange costs since it delivers effective coordination, administration and utilization of data. cell phones which uses Internetassociated IT brings down exchange costs as it gives both off-site access to the company's internal database and other significant sources of information. The outcome further reduces the cost of operation by the introduction of mobile and agency banking which influences the profitability growth of the bank. This theory is then believed to be a guideline as regards the study on factors that influence financial innovations on financial performance of commercial.

\subsection{Review of Empirical Studies}

This basically looks into a direct analysis of published works which includes; periodicals and books and further explains the theory that brings out findings about that are pertinent to the research theme within reach (Zikmund et al., 2010), unlike in review of literature which brings forth the overlook and an analyzed survey of the former queries which were brought up and which related to a research question. Outlining the study straightforwardly identified with the research hypothesis as compared to the overall studying of the wide in scope and covering a number of years should be upheld (Kaifeng \& Miller, 2008). It can hence be concluded that review of literature permits an investigator to put up into intellectual and 
historical context the research by the help of systematic approach to previous scholarship and it also helps the researcher affirm the importance of their research.

\subsubsection{Online Banking}

Information and communication technology is currently the trendiest and significant factor in the banking sector as refers to the banking industry where information, communication and technology is the purpose behind development in the economy. E-banking framework has developed the principle innovation compelled confusion in leading monetary exchanges as financial organizations have invested significantly in telecommunication and electronic frameworks and the users have sanctioned and acknowledged e-banking framework as valuable and simple to utilize (Adesina and Ayo, 2010). The restructure in the banking industry has increased as a result of ICT advancements, competition, globalization, and changing social trends which includes improvement of customer pro-activeness and improvement in convenience (Loonam and O'Loughlin, 2008).

According to Chung and Dutta (2012), the use of e-banking is now common and financial institutions have also acknowledged the potentiality in the internet banking sector and have appreciated the need for integration of the customers' lifestyle and internet facilities in their organization models. Approval of e-banking enable cost reduction and increased profit making by the banks. The coming up of online banking has resulted to unprecedented speed growth and a major global purpose in banking systems. E-banking improves financial institution and this as well has enabled users to have secure transaction process. E-commerce has resulted to increased business trend in commercial transaction, turnover ratio and sales. Ram, et al (2008) looked into the effect of e-banking force on the profitability of banking sectors and it was noted that the real effect of e-banking was measured on the performance indicated through reverting of the efficiency in profit index against an amount of correlated involving intensive measures on online. The outcome showed an increase in the adoption of technology as a convenient form of selling and advertising services of banks has increasingly raised profits of community banks.

\subsubsection{Electronic Funds Transfer}

A study by Agboola (2006), was based on ICT in financial sector which target banks in Nigeria. It investigates on the use of innovation and the effect of ICT adopted in the banking sector. An increase in the adoption of electronic home, smart cards, EFT, ATMs, agency banking and M-banking was witnessed and a further conclusion indicated that adoption of ICT led to improvement of the financial institutions' good reputation and brings about a broader, quicker and more market efficiency. Agboola further asserted that it is very important for bank management to ensure increase in investment in ICT products to facilitate speed, convenience, and accurate services, or otherwise lose out to their competitors.

An examination done by Mabrouk and Mamoghli (2010) on Dynamics of Financial Innovation and Performance of Banking Firms: Context of an Emerging Banking Industry, investigated the impact of the endorsement of two kinds of monetary innovations to be specific; product development (M-banking and SMS banking et cetera) and process development (Magnetic strip card (debit, ATM and Debit/credit card), Automatic money dispenser; (Automatic teller machine; Electronic payment terminal et cetera) on the performance of banks. Their investigation included two factors, first mover in appropriation of financial innovation and imitator of the first innovator. They discovered that first innovator activity in product advancement enhances benefit while process initiative has a positive effect on profitability and efficiency.

\subsubsection{Mobile Banking}

Mobile banking has generally brought about mixed reactions in areas mostly where cellophanes have shown the fastest and quickest mode of communications of its own kind. Cellophanes have enhanced quick mode of communication at a reduced rate and the same has hence facilitated individuals as well as organization to quickly and cheaply pass and receive information on various issues both in economically, socially and politically aspects. Upcoming research bodies showing reduction in communication costs and which is related to mobile phones has benefits economic wise, improved agricultural and labour market efficiency and producer and consumer welfare in specific circumstances and countries. Jensen, 2007; Aker, 2008; Klonner \& Nolen, 2008 noted that improving maturity as regards telecommunication markets and evolution of mobile phones from easy way of passing information to delivering the information tool is yet to be achieved and can be proved as a result of the shifted in the development paradigm surrounding mobile phones which explains the reduction of passing the information and the expenses involved in changing people's lives through application of innovation and services.

According to Aker and Mbiti (2010) they discovered a there is relationship between mobile phone coverage, services rendered, cost for the service and organizational performance and is of the view that firms with markets which has less stiff competitors and profit-maximizing need to give scarce service at inflated costs. Rayhan et al (2012) while looking into the issue of mobile banking in Bangladesh wrap up the study and stated that mobile banking brings about the prospective to increase low cost virtual bank accounts to a large number of currently un-banked individuals. Mobile phone leads to enhanced ability of offering solutions in regard to e-banking answers which give clients a wide variety of service options at a cheaper price. M-banking is explained as to it being a real time on-line banking, available anytime and anywhere throughout the country and its importance includes; convenient, affordable, secure and encourages efficient savings thus raising bank deposits. M-banking helps in easy and quick accessibility to bank services at lower charges. Most importantly, positive aspect of mobile phones is that mobile networks reach remote areas at an affordable cost for both to the consumer and the bank. 


\subsubsection{Agency Banking}

Gardner (2000) in his study of agency banking asserted that operating agent banking systems is three times cheaper than their branches for the following two reasons being; Firstly, agent banking has decreased fixed costs by bringing to the same level existing retail outlets and reducing the need for financial agent banks to invest in their own infrastructure. Secondly, he observed that fixed costs per transaction for branches are increasingly higher than agent banking which incurs higher variable costs from commissions to agents and communications.

Central bank is regulatory agency in the banking sectors to ensure that banks are following ethics in there conduct and secure the customers and other industries from any corporate misconduct. They are the moving block that has assisted the banking sector in developing the agency banking and its implementation. Central Bank of Kenya was able to prepare policies and framework in 2009 that would foster growth of agency banking in Kenya. It first tract banking act that would enable the banks to develop agents in main areas like petrol station, retail shops among other areas to enable growth in Kenya. It also created the framework for the implementation of agency banks to ensure security and transaction within banking sector and private agent (owners). This was to improve the performance as well as create jobs. Therefore, it has led to introduction bank agents in parts of the country (Baron 2002). Thus, this has contributed to praises from customers because of easy accessible of banking services in various parts of the country hence developing high levels of financial literacy.

Berger (1998) pointed out that the agent banks, just like real banks offer similar services. He came up with a range in which; cash deposits and withdrawals, disbursement and repayment of loans, payment of salaries, pension, transfer of funds, and issuance of mini-bank statements, among others are between. He also noted that agency bring about new and increased opening of new accounts, application of credit and debit card, demand of cheque books, which leads to reduction of banks opening and having branches all over. This has been adopted across the country, especially in rural areas and is currently working out. The Kenyan situation remains an important case study in this regard as the Central Bank has already approved four banks to perform agent banking business and licensed 8,809 agents and many others are expected to be licensed in due course. This is expected to deeply boost penetration of low cost banking services in the country.

\subsection{Research Hypothesis}

The paper was to test the following research hypothesis.

- $\mathrm{H}_{01}$ : Online banking does not have significant effect on performance of commercial banks in Kenya.

- $\mathrm{H}_{02}$ : There is no significant influence of electronic funds transfer on financial performance of commercial banks in Kenya.

- $\mathrm{H}_{03}$ : Mobile banking does not have significant effect on performance of commercial banks in Kenya.

- $\mathrm{H}_{04}$ : There is no significant effect of agency banking on financial performance of commercial banks in Kenya.

\section{Research Methodology}

Causal research design was used to outline the objective of finding affiliations and causal relationships among various variables. The target population for this research included 215 employees drawn from 43 commercial banks. The sample was calculated using the Yamane formula which assumes a normal distribution. That is $n=N / 1+N(e){ }^{2}$ where $n$ is the sample size is, $\mathrm{N}$ is the population size and e is the error of sampling. This study allowed the error of sampling on 0.1. The sample size was therefore 170 respondents.

$\mathrm{N}=215 / 1+215\left(0.05^{2}\right)$

$=215 / 1.25=170$

The sample population was obtained using stratified sampling technique from the population from all department. The data was collected then analyzed using inferential statistics.

\section{Results and Discussions}

Inferential statistics were given by coefficient of determination, ANOVA and regression model which tested the relationship between agency banking, EFT, Online Banking and M-banking on the financial performance of banks.

\begin{tabular}{rl|c|c|c|c|}
\hline Model & R & R Square & Adjusted R Square & $\begin{array}{c}\text { Std. Error Of The } \\
\text { Estimate }\end{array}$ \\
\hline 1 & $.820^{\mathrm{a}}$ & .672 & .664 & .45412 \\
\hline \multicolumn{4}{c}{$\begin{array}{r}\text { Table 1: Coefficient of Determination } \\
\text { Source: Research Data (2017) }\end{array}$} \\
A. Predictors: (Constant), Agency Banking, EFT, Online Banking, M-Banking
\end{tabular}

The coefficient of determinant indicates that $\mathrm{R}^{2}=67.2 \%$ implying that independent variable can predict the dependent variable at $67.2 \%$. Also, the variation between dependent and independent variable is explained by $67.2 \%$. This shows a relationship between dependent and independent variables. 


\begin{tabular}{|l|l|l|l|l|l|c|}
\hline \multicolumn{2}{|c|}{ Model } & \multicolumn{1}{|c|}{$\begin{array}{c}\text { Sum of } \\
\text { Squares }\end{array}$} & Df & Mean Square & F & Sig. \\
\hline \multirow{2}{*}{1} & Regression & 67.707 & 4 & 16.927 & 82.079 & $.000^{\mathrm{b}}$ \\
\cline { 2 - 7 } & Residual & 32.996 & 160 & .206 & & \\
\cline { 2 - 7 } & Total & 100.703 & 164 & & & \\
\hline
\end{tabular}

Table 2: ANOVA

Source: Research Data (2017)

A. Dependent Variable: Financial Performance

B. Predictors: (Constant), Agency Banking, EFT, Online Banking, M-Banking

The ANOVA indicated that there was significant $(\mathrm{p}<0.05)$ relationship between the dependent variable and independent variable. There is no significant difference between independent and dependent variable with $\left(\mathrm{F}_{\mathrm{p}=0.95}=82.079\right)$.

\begin{tabular}{|c|l|l|l|l|l|l|}
\hline \multicolumn{2}{|c|}{ Model } & \multicolumn{2}{c|}{$\begin{array}{c}\text { Unstandardized } \\
\text { Coefficients }\end{array}$} & $\begin{array}{l}\text { Standardized } \\
\text { Coefficients }\end{array}$ & T & Sig. \\
\cline { 3 - 7 } \multicolumn{2}{|c|}{} & B & $\begin{array}{l}\text { Std. } \\
\text { Error }\end{array}$ & Beta & & \\
\hline \multirow{3}{*}{1} & (Constant) & 1.586 & .452 & & 3.512 & .001 \\
\cline { 2 - 7 } & Online Banking & .037 & .055 & .031 & .682 & .496 \\
\cline { 2 - 7 } & EFT & .083 & .059 & .063 & 1.393 & .166 \\
\cline { 2 - 7 } & M-Banking & .325 & .041 & .813 & 17.737 & .000 \\
\cline { 2 - 7 } & Agency Banking & .152 & .051 & .072 & .046 & .043 \\
\hline
\end{tabular}

Table 3: Regression Model

a. Dependent Variable: Financial Performance

Source: Research Data (2017)

The results indicate that online banking had no significant influence on financial performance. The significance level for the $\mathrm{t}$-statistic is greater than $0.05(\mathrm{P}=0.496)$ as indicated hence the study accept the null hypothesis which states that Online banking does not have significant effect on performance of commercial banks in Kenya. Online banking results were found to be positive predictor with no significance in financial contribution. These results do not concur with Simpson (2002) idea that online banking is motivated largely by the prospects of operating costs minimization and operating revenues maximization. This implies that online banking is reliable in minimizing operational costs that contribute to the poor financial performance of commercial banks in Kenya.

The result also indicated that electronic funds transfer (EFT) has no significant influence on financial performance. The significance level for the t- statistic is greater than $0.05(\mathrm{P}=0.166)$ as indicated hence the study accept the null hypothesis which states that electronic funds transfer does not have significant influence on financial performance of commercial banks in Kenya. EFT results were found to be positive predictor with no significant in financial contribution. This result does not concur with Hernando and Nieto (2006) study that internet delivery channels which are highly used in electronic money transfer change bank's performance, they found out that adoption of internet as a delivery channel involved gradual reduction in overhead expenses (particularly, staff, marketing and IT) which translates to an improvement in banks' profitability. This implies that EFT had little influence on financial performance of commercial banks in Kenya.

The Result also indicated that mobile banking has significant influence on financial performance. The significance level for the t-statistic less than $0.05(\mathrm{P}=0.000)$ as indicated hence the study was in reject with the null hypothesis which states that Mobile banking does not have significant effect on performance of commercial banks in Kenya. This result concurs with Rayhan, Sohel, Islam, and Mahjabin (2012) study on mobile banking where they found out it offers the potential to extend low cost virtual bank accounts to a large number of currently un-banked individuals. Mobile phones enhance the ability of electronic banking solutions to offer customers an enhanced range of services at a low cost. Mobile banking is real time on-line banking, available anytime, anywhere throughout the country, it is convenient, affordable and secure and therefore it is much more effective in developing savings habits and hence leading to increase in bank deposit and their financial base.

Lastly, the result indicates that agency banking has significant influence on financial performance. The significance level for the t-statistic less than $0.05(\mathrm{P}=0.043)$ as indicated hence the study was not in agreement with the null hypothesis which states that is no significant effect of agency banking on financial performance of commercial banks in Kenya. This result concurs with Kasekende (2008) study where found out that Agency banking has increased territory, reached marginalized and customer base hence improving on their financial performance. This implies that agency banking is play a significant role in the performance of commercial banks in Kenya. 


\section{Conclusions and Recommendations}

From the findings, it can be concluded that there exists significant effect of the innovation on the performance of the bank in terms of the number of customer base which interpret to high liquidity, low solvency and hence indirect financial performances. The financial performance was not linked directly to the innovation though mobile banking had direct contribution to financial performance through commission and charges for transaction. Agency banking also contributed to the performance of the commercial banks. EFT and online banking on contrary did not significantly influence financial performance of the banks. But it was highly associated with the growth and customer base ability to access service suitable for a certain market niche.

The study recommends that banks should transform banking service by adapting to mobile banking and agency banking so that not only to providing jobs but also increase market share. It would beneficial where banking has not reached and improve security. Agency bank has been practiced by few banks that is why the number is still less. On the other hand, the bank should create awareness on service that are available in the online through providing alternative technology that can be used in PDA including mobile applications.

\section{Acknowledgement}

I acknowledge my supervisor Dr. Charles Tibbs for his contribution through the research work.

\section{References}

i. Bhattacharyya, S. and Nanda, V.K. (2000). Customer circumspection, exchanging costs and financial advancement. Review of Financial Studies, 13, 1101-1127.

ii. Gardachew, W. (2010). Electronic-management of accounts in Ethiopia: Practices, and challenges. Journal of Internet Banking and Commerce 79, 223-255.

iii. Lerner, J. (2006). The new financial thing: The origins of financial innovations. Journal of Financial Economics, 79, 223-255.

iv. Lyons, R. K, J. A Chatman \& C. K. J (2012). Innovation in financial services: Corporate culture and investment banking. California Management Review, 50(1), 174-191.

v. Mabrouk, A., \& Mamoghli, C. (2010). Dynamic of financial innovation and performance of banking firms: Context of an emerging banking industry. International Research Journal of Finance and Economics, 5, 2010. 